\title{
Self-association of the anionic form of the DNA binding anticancer drug Mithramycin
}

\author{
Shibojyoti Lahiri ${ }^{\S}$, Pukhrambam Grihanjali Devi ${ }^{\S}$, Parijat Majumder ${ }^{\S}$, \\ Suman Das ${ }^{\dagger}$, and Dipak Dasgupta* \\ Biophysics Division, Saha Institute of Nuclear Physics, \\ 1/AF Sector-1, Bidhannagar, Kolkata-700064, INDIA
}

*To whom correspondence should be addressed:
Email: dipak.dasgupta @ saha.ac.in;
Tel.: +91-033-23370379; Fax: +91-033-23374637
§ These authors contributed equally to the work.
† Present address: Department of Chemistry, Maulana Azad College, 8 Rafi Ahmed
Kidwai Road, Kolkata 700013, INDIA

The supporting information provides complementary experimental results and do not present any novel finding or facts exceeding the principal information of the paper. Nevertheless the results obtained for an extended experimental range may be of interest for some readers. Furthermore this information can be taken as a further justification for the discussions and conclusions. 
Figure S1: NOESY spectra of MTR $(1 \mathrm{mM})$ in $20 \mathrm{mM}$ phosphate buffer, $\mathrm{pH} 8.0$ at $25^{\circ} \mathrm{C}$ showing the cross-peak between (A) $\mathrm{C}^{-}-\mathrm{CH}_{3}$ and DC6"-H $(2.0,0.09)$ and (B) $\mathrm{C}^{\prime}-\mathrm{OH}$ and $\mathrm{Cl}^{\prime \prime}-\mathrm{H}(\mathrm{e})(6.6,5.4)$ and $\mathrm{C}^{\prime}-\mathrm{OH}$ and $\mathrm{C} 1^{\prime \prime}-\mathrm{H}(\mathrm{a})(6.4,5.2)$
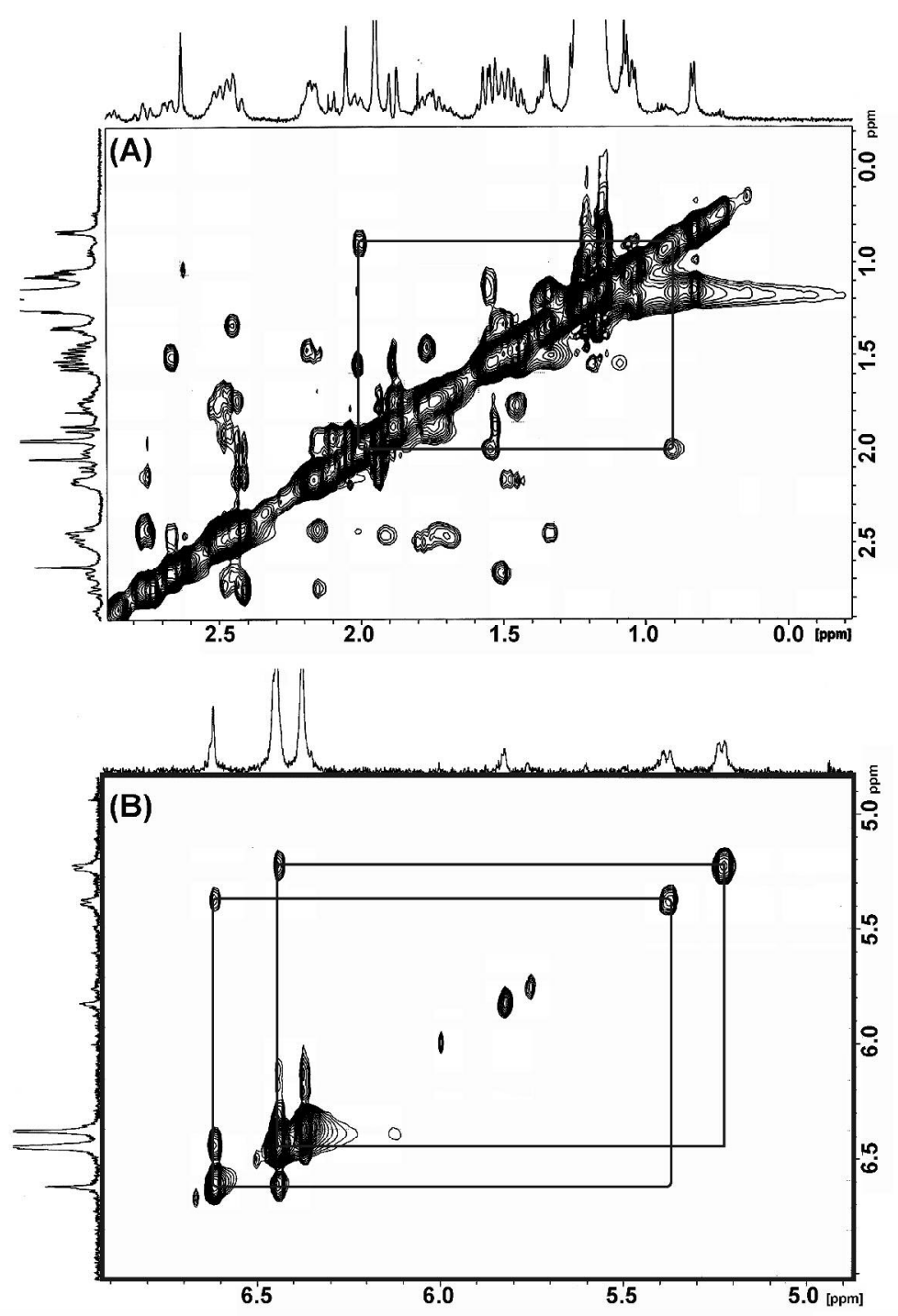
Figure S2: $1 \mathrm{D}{ }^{1} \mathrm{H}$ NMR spectra showing concentration dependence of $\delta$ value of (A) $\mathrm{C}^{\prime}-\mathrm{CH}_{3}$ of anionic MTR in $20 \mathrm{mM}$ phosphate buffer, $\mathrm{pH} 8.0$ at $25^{\circ} \mathrm{C},(\mathbf{B}) \mathrm{CC} 1^{\prime \prime}-\mathrm{H}$ of anionic MTR, (C) $\mathrm{C}^{\prime}-\mathrm{CH}_{3}$ of $\left[(\mathrm{MTR})_{2} \mathrm{Mg}^{2+}\right]$ complex and (D) $\mathrm{CC} 1^{\prime \prime}-\mathrm{H}$ of $\left[(\mathrm{MTR})_{2} \mathrm{Mg}^{2+}\right]$ complex.

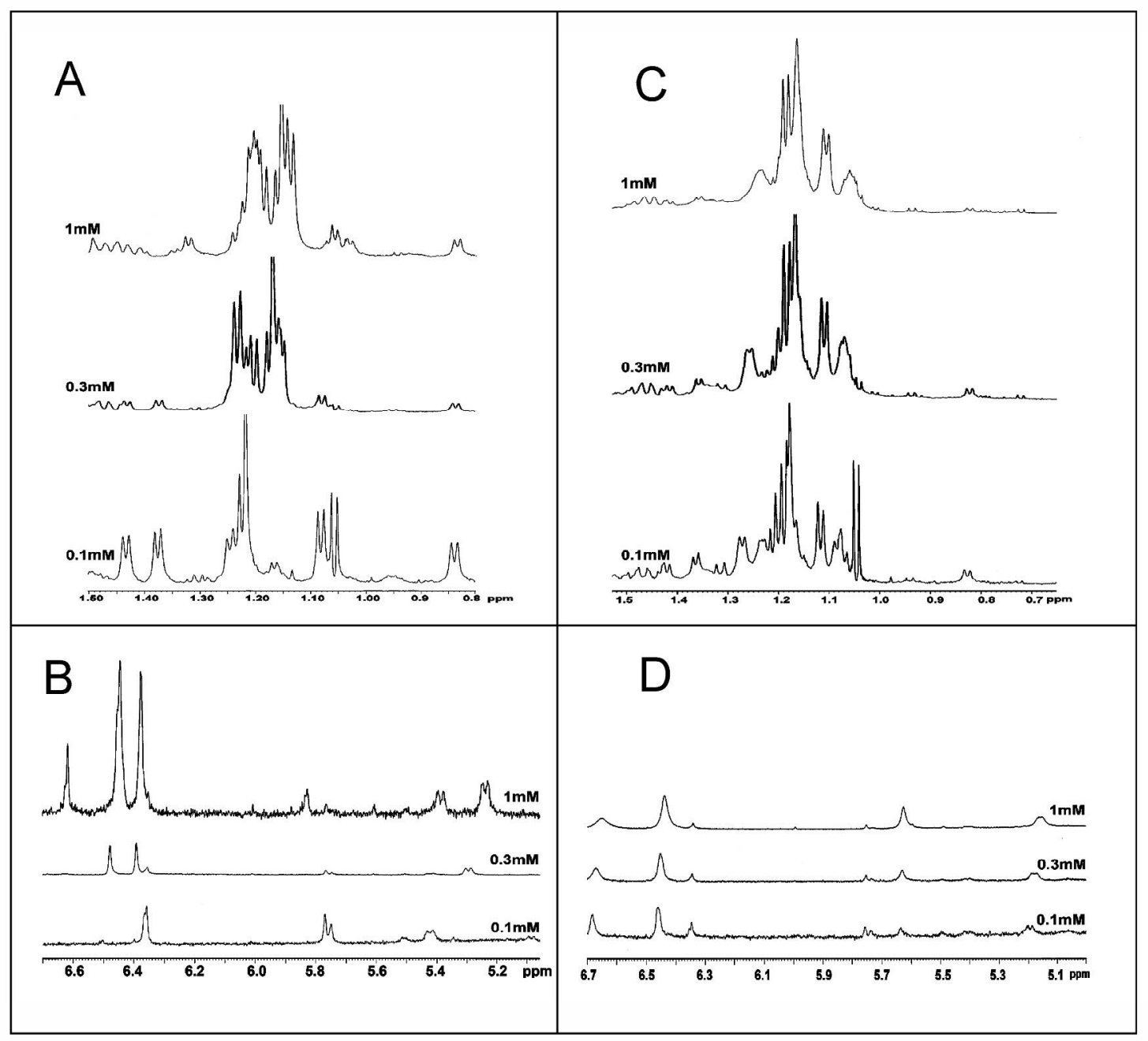


Figure S3: NOESY spectrum of $\left[(\mathrm{MTR})_{2} \mathrm{Mg}^{2+}\right]$ complex in $20 \mathrm{mM}$ phosphate buffer, $\mathrm{pH}$ 8.0 at $25^{\circ} \mathrm{C}$.

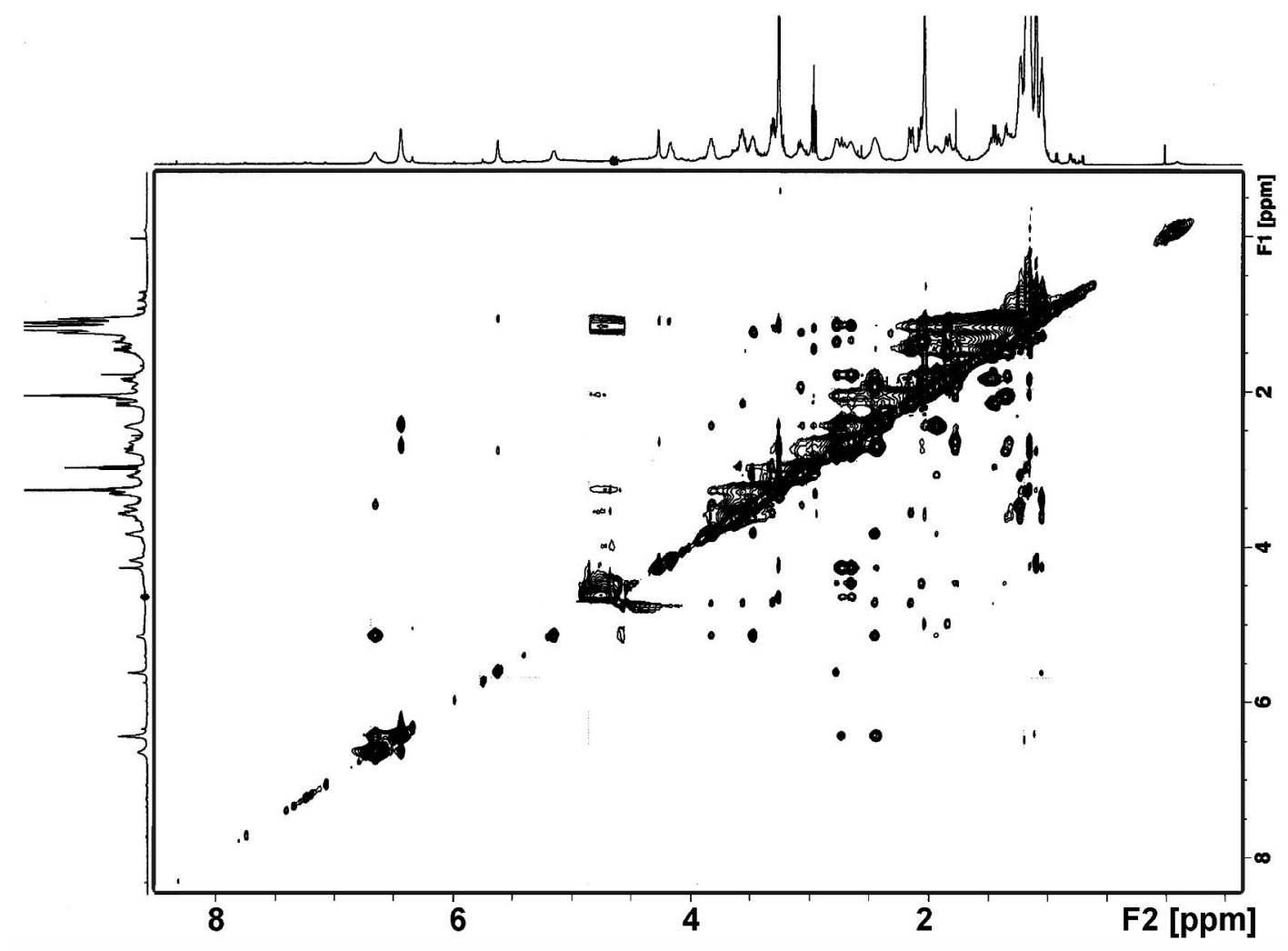

